University of Nebraska - Lincoln

DigitalCommons@University of Nebraska - Lincoln

Faculty Publications from the Harold W. Manter Laboratory of Parasitology

4-1980

\title{
Sarcocystis of Passerine Birds: Sexual Stages in the Opossum (Didelphis virginiana)
}

\author{
Edith D. Box \\ University of Texas Medical Branch \\ Donald W. Duszynski \\ University of New Mexico, eimeria@unm.edu
}

Follow this and additional works at: https://digitalcommons.unl.edu/parasitologyfacpubs

Part of the Parasitology Commons

Box, Edith D. and Duszynski, Donald W., "Sarcocystis of Passerine Birds: Sexual Stages in the Opossum (Didelphis virginiana)" (1980). Faculty Publications from the Harold W. Manter Laboratory of Parasitology. 188.

https://digitalcommons.unl.edu/parasitologyfacpubs/188

This Article is brought to you for free and open access by the Parasitology, Harold W. Manter Laboratory of at DigitalCommons@University of Nebraska - Lincoln. It has been accepted for inclusion in Faculty Publications from the Harold W. Manter Laboratory of Parasitology by an authorized administrator of DigitalCommons@University of Nebraska - Lincoln. 


\section{Sarcocystis OF PASSERINE BIRDS: SEXUAL STAGES IN THE OPOSSUM (Didelphis virginiana) ${ }^{\text {田 }}$}

EDITH D. BOX and DONALD W. DUSZYNSKI, Department of Microbiology, University of Texas, Medical Branch, Galveston, Texas 77550, USA.

Abstract: Sexual stages of a Sarcocystis of passerine birds were demonstrated by feeding muscle cysts from cowbirds (Molothrus ater) and grackles (Cassidix mexicanus) to opossums (Didelphis virginiana). Opossums were examined at necropsy at $36 \mathrm{~h}, 13.5$ days, and 29.5 days post-inoculation (PI). Large numbers of macro- and microgamonts were present in the small intestine $36 \mathrm{~h}$ PI, while only sporocysts and oocysts were present 13 days or more PI. Microgamonts in different stages of development were in the intestinal epithelium above the nucleus and macrogamonts were at the base of the epith elial cells or in the lamina propria. Oocysts and sporocysts were in the core of the villus, beneath the basement membrane. Descriptions are given of the sexual stages as they appear in sections and smears.

\section{INTRODUCTION}

Muscle parasites belonging to the genus Sarcocystis have been shown to require alternation of hosts with a predator representing the definitive host and its prey representing the intermediate host. Fecal sporocysts from the definitive host are infectious for the intermediate host in which the sporozoites initiate asexual reproduction eventually producing muscle cysts infectious for the predator. Sexual stages from the intestine of the predator have been described for Sarcocystis of sheep, $1,8,9$ cattle, ${ }^{5,11}$ rats, ${ }^{1: 3}$ and mice, ${ }^{10}$ but the only description of sexual forms of avian species has been from tissue culture. ${ }^{4,12}$

In earlier papers, we described the experimental infection of opossums (Didelphis virginiana) with Sarcocystis $\mathrm{sp}$. from muscle cysts of three icterid bird species (the brownheaded cowbird, Molothrus ater; the boat-tailed grackle, Cassidix mexicanus; and the common grackle, Quiscalus quiscula). ${ }^{3}$ Sporocysts from these opossums proved to be infectious for English sparrows (Passer domesticus) and canaries (Serinus canarius). ${ }^{2}$ Intestinal forms from opossums infected during these ex. periments are described below.

\section{MATERIALS AND METHODS}

Animals: Opossums which had been wild-caught 2 to 3 months earlier were purchased from the University of Texas Science Park, Bastrop, Texas. During captivity, they were fed dry commercial dog chow. As opossums are nocturnal animals, infected bird carcasses were substituted for the chow in the late afternoon and removed in the morning, approximately $16 \mathrm{~h}$ later. Therefore, the time of necropsy postinoculation (PI) was expressed as a midpoint and is $\pm 8 \mathrm{~h}$. Feces were collected in the morning and examined for sporocysts by sugar flotation. Fecal examinations for more than 2 months before experimental infections showed several helminth infections, but no coccidia were found.

Three opossums were infected and then examined at necropsy to show early

\footnotetext{
1 This invegtigation was supported in part by NIH Research Grant No. AI 15945.

(2) Department of Biology, University of New Mexico, Albuquerque, New Mexico 87131, USA.
} 
and late sexual stages of Sarcocystis from two bird species, Cassidix mexicanus and Molothrus ater. One opossum was given infectious meals of $C$. mexicanus at 2 separate times so that necropsy was at $36 \mathrm{~h}$ and 29.5 days PI. Sporocysts were found in the feces of this opossum at 10 days PI. A second opossum was given 3 infected cowbirds and killed $36 \mathrm{hrs}$ PI. The third opossum was given 6 cowbirds over a period of 2 days and necropsied 13.5 days after its first infective meal. No feces were deposited by this host on day 10 PI but sporocysts were seen in its feces on day 11 PI (2 days before necropsy).

Necropsy: The small intestine was removed, divided into 10 approximately equal segments ca $10-12 \mathrm{~cm}$ each, and the mid $2-4 \mathrm{~cm}$ from each segment was slit lengthwise, placed serosal surface down on a strip of filter paper and fixed in 100 $\mathrm{ml}$ of cold Helly's and Bouin's. Sections cut at ca $6 \mu \mathrm{m}$ thick were stained with haematoxylin and eosin (H\&E) and periodic acid Schiff's reaction (PAS). Also, at necropsy, a smear of the mucosa from each segment was fixed in Bouin's and stained with Giemsa's.

\section{RESULTS}

Because available evidence suggests that the grackle and cowbird Sarcocystis are the same species, ${ }^{2}$ observations from opossums infected from either avian species are combined for descriptions of the sexual stages.

Gamonts: These stages were very abundant in $36 \mathrm{~h}$ infections. They were present in all 10 intestinal segments but were somewhat more plentiful in segments 2 to 5 and least plentiful in segments one and 10. In tissue sections taken 36 h PI, numerous macrogamonts were seen aligned at the base of enterocytes above the basement membrane (Fig. 1) as well as within the lamina propria of the villi. Each macrogamont appeared to be within a vacuole enclosed by a wall staining pink with $\mathrm{H} \& \mathrm{E}$ and PAS, possibly remnants of a host cell (Fig. 2). Macrogamonts were round to oval, $5.5 \times 5.9 \mu \mathrm{m}(4.5-7 \times 4.5-8$, $\mathrm{n}=20$ ). When stained with $\mathrm{H} \& \mathrm{E}$, they were blue-grey with a nucleus ca $2-3 \mu \mathrm{m}$. No nucleolus was visible, nor was a definite oocyst wall seen. The cytoplasm contained vacuoles which appeared refractile. When stained with $\mathrm{PAS}$, the macrogamonts contained red granules in the cytoplasm on the periphery of the cell (Figs. 1 and 2). In many of the macrogamonts, these granules had coalesced. Macrogamonts in smears stained with Giemsa (Fig. 3) were larger, $8.4 \times 9.6 \mu \mathrm{m}(7.11 \times 7.12, \mathrm{n}=20)$ than those in sections and the portion of the cell occupied by the nucleus varied from ca $2 / 3$ for smaller gamonts to $1 / 3$ for the larger forms. Cytoplasmic granules stained a dark blue and appeared to migrate to the edge in older forms. A few forms were found with division of the nucleus or a refractile-appearing wall suggesting the beginning of sporogony.

Most microgamonts were observed above the nucleus in the epithelial cells (Figs. 1 and 4). Frequently there appeared to be a clustering of microgamonts and as many as five were found infecting the same epithelial cell. Young microgamonts were identified by their dividing nuclei and cytoplasm with large irregular vacuoles (Fig. 4). All stages in development were found, from uninucleate to mature gamonts. In sections, microgamonts containing 4-10 gametes were $5.1 \times 5.5 \mu \mathrm{m}(4-6 \times 5-6$, $\mathrm{n}=10$ ). The structure of the microgamont was more obvious in smears because the parasite was spread out and hence larger. Sizes ranged from elongate forms with undivided nuclei ca $3 \times 7 \mu \mathrm{m}$ to forms with spindle-shaped gametes ca 10 $\times 10 \mu \mathrm{m}$ (Fig. 6). Thirteen to 17 nuclei were counted in gamonts in which nuclear division appeared to be complete (Figs. 5 and 6). Gametes in smears measured ca $0.75 \times 6 \mu \mathrm{m}$ and had two flagella ca $8 \mu \mathrm{m}$ long (Fig. 7).

Sporocysts: All sporocysts were fully formed and contained sporozoites in the 
FIGURES 1 \& 2 . PAS stained sections of intestine from opossums.

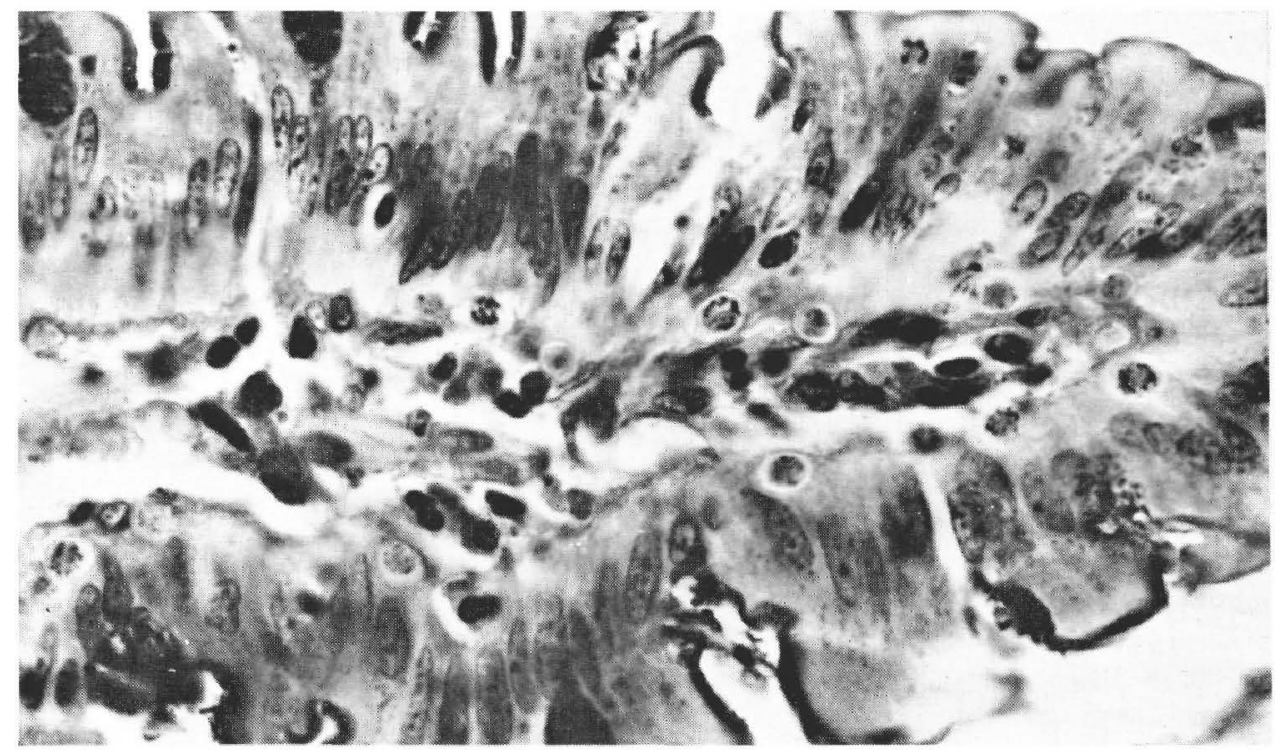

FIGURE 1. $36 \mathrm{hr}$. PI. Note numerous macrogamonts at the base of epithelial cells in parasitophorous vacuoles. Two microgamonts are visible in the epithelium (arrows). $\times 731$
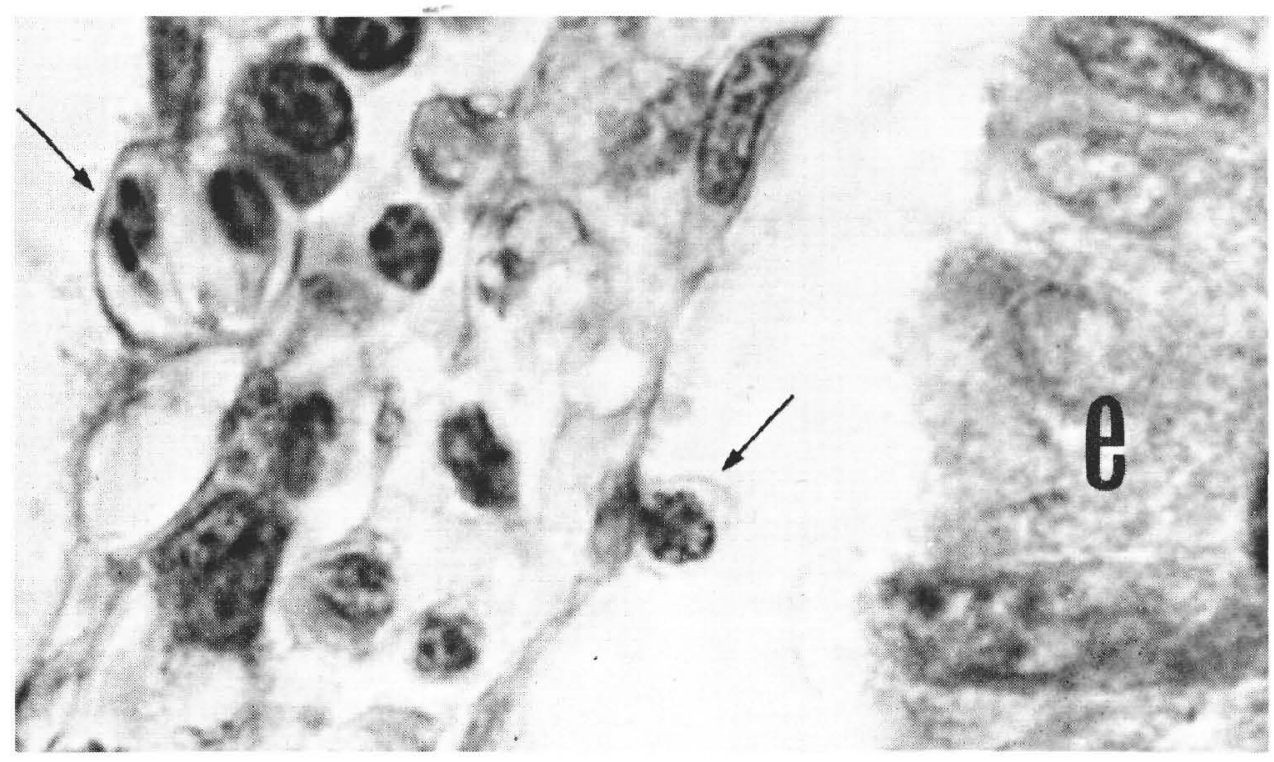

FIGURE 2. Double infection $38 \mathrm{hr}$. and 13.5 days PI. A macrogamont in a vacuole surrounded by a thin wall (right arrow) attached to the core of the villus and a sporulated oocyst (left arrow) embedded in the core of the villus which is shrunken from the epithelium (e). $\times 1625$ 
animals necropsied 13.5 and 29.5 days PI. Some were in pairs within a thin oocyst wall (Figs. 2 and 8 ), but most appeared to be separate. As would be expected, sporocyst distribution was similar to that of the gamonts. They occurred throughout the small intestine but were most plentiful in segments 2 to 5 . Sporocysts were in the core of the villus (Fig. 2) and more were seen at the tips of the villi than toward the crypts. There was no evidence of delayed development, i.e., gamonts were not found in the opossum necropsied 13.5 days PI. Sporocysts and oocysts were not measured in sections because of the distortion of the sporocysts when subjected to fixatives and dehydration. In smears, sporocysts measured $7.6 \times 10.7 \mu \mathrm{m}(6-9 \times$ $9-12, \mathrm{n}=10)$ and oocysts $10.7 \times 13.9 \mu \mathrm{m}$ (10-12 $\times 13-15, n=10)$. Residual bodies which are prominent in fecal sporocysts were not seen in sporocysts in tissue sections or smears.

Sporozoites: Sporozoites (Figs. 9 and 10) measured $1.1 \times 5.5 \mu \mathrm{m}(1-1.5 \times 5-6$, $\mathrm{n}=10)$ in sections and $1.0 \times 5.8 \mu \mathrm{m}(1-1.5 \times$ $5-6, n=10)$ in smears. The nucleus was at the posterior (blunt) end and PAS positive granules were scattered in the middle portion (Fig. 9). No refractile body was seen.

\section{DISCUSSION}

This is the first report on the endogenous development of an avian Sarcocystis in its natural definitive host. Fayer, ${ }^{4}$ in his pioneering tissue culture of Sarcocystis from the grackle (Quiscalus quiscula), may have been working with the same or a closely related species to the one described in this paper. His parasites developed rapidly into gamonts at $30 \mathrm{~h}$, and by $48 \mathrm{~h}$, all parasites were "cyst-like"; however, no sporogony was noted. Similarly, in our experiments, gametogony was essentially complete in the opossum intestine at 36 h PI. Unfortunately, we were unable to observe the development of the zygote into oocyst and sporocysts because our next necropsy (13.5 days PI) was done too long after fertilization occurred. However, as we previously reported, " the earliest time that fecal sporocysts were detected in the opossum, was 5 days after an infectious meal indicating that development of some of the sexual stages was complete prior to 5 days PI. This rapid development compares with that of Sarcocystis muris in which sporocysts were also first found at 5 days $\mathrm{PI}^{10}$ but it appears to be shorter than sporogony of Sarcocystis of cattle and sheep. Macrogamonts of $S$. bovicanis were found by Fayer in the dog intestine from days 2 to $13 \mathrm{PI}$ and the prepatent periods were 9 to 22 days. ${ }^{5}$ Scholty seck and Hilali reported an unusually long developmental time for $S$. fusiformis of sheep in which gamonts were found in the cat intestine on days 13-14 PI. ${ }^{11}$

Mehlhorn and Heydorn ${ }^{7}$ suggested that the long patent period characteristic of intestinal Sarcocystis infection may be because gamonts do not all develop at the same time. In our experiments the fact that all sporocysts appeared to be fully mature by 13.5 days PI suggests that delayed development is not responsible for prolonged fecal passage of sporocysts which as we reported earlier extended for at least 15 weeks in two opossums. ${ }^{3}$ Close synchronization of sexual development was also reported for a species of sheep Sarcocystis in the fox intestine. ${ }^{1}$ Prolonged patency in Sarcocystis infections probably occurs because sporocysts trapped in the lamina propria are periodically forced out of the villi, principally at the tips, by intestinal contractions.

The sexual stages of the passerineopossum Sarcocystis are generally comparable to those described for other species. ${ }^{6,7}$ Gamonts and sporocysts are distributed throughout the small intestine with a predominance at the upper middle. Macrogamont development below the epithelium and microgamont development in the epithelial cells at the 


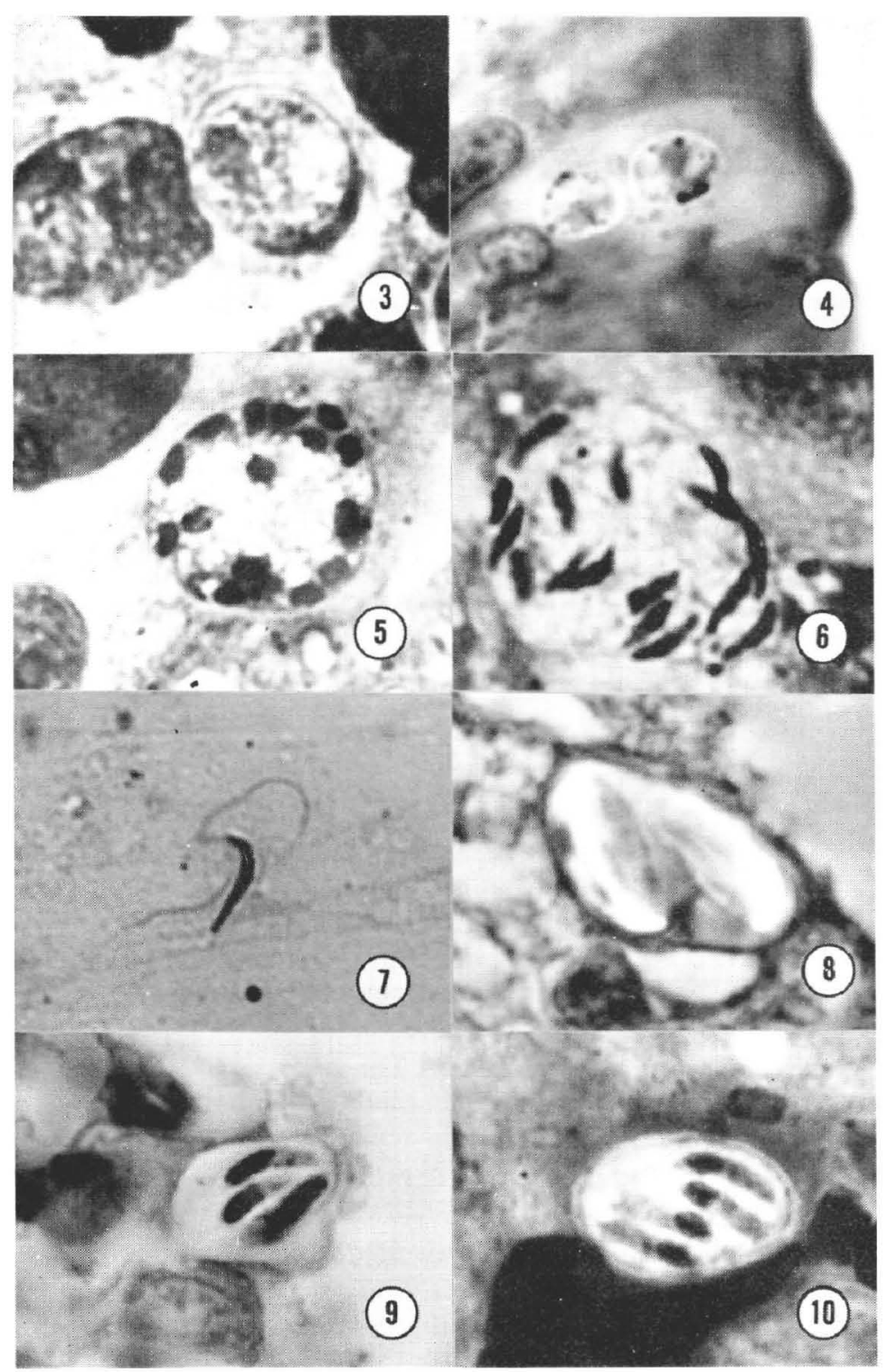

FIGURES 3-7. Opossum intestine, 36 hr. PI. $\times 3000.3$. Macrogamont in Giemsastained smear. 4. Two microgamonts in epithelial cell. PAS stained section. 5. Microgamont with 16 nuclei. Giemsa-stained smear. 6 . Microgamont showing spindle shaped gametes. Giemsa-stained smear. 7. Microgamete in Giemsa-stained smear.

FIGURES $8 \& 9$. Sections of opossum intestine, $10-13$ days PI. $\times 3000.8$. Oocyst from core of villus showing thin wall enclosing 2 sporocysts. Phase, H\&E. 9. Sporocyst with sporozoites. PAS positive granules plus nucleus account for the dark area in posterior of sporozoite. Compare with Fig. 10.

FIGURE 10. Giemsa-stained smear from opossum intestine 29 days PI. $\times 3000$. Sporocyst containing 4 sporozoites showing nuclei at posterior end. 
surface of the villus has also been reported for other species of Sarcocystis studied. ${ }^{7}$ Although remnants of the host cell were seen surrounding the macrogamont, we could not determine if the host cells were sunken epithelial cells as suggested by Mehlhorn and Scholtyseck. ${ }^{8}$ As sporogony progresses, the macrogamonts appear to descend from the base of the epithelial cells to the core of the villus. The relative position of the macrogamont and sporulated oocyst can be seen in Fig. 2 which is a section from a doubly infected opossum. The core has separated from the epithelium and, although the oocyst is embedded in the core, the macrogamont appears to be attached to and above the basement membrane.

Microgamonts have been missing or rare in most experimental infections.
Their comparative abundance in this study may have been a consequence of the rapid development of the avian species. The number of microgametes per microgamont found in smears (13 to 17) is more than the maximum of 12 nuclei found in tissue culture of the grackle species ${ }^{4}$ but is less than the 20 to 30 nuclei reported by Mehlhorn and Heydorn ${ }^{7}$ as a maximum for mature microgamonts. The size of microgametes in our species was ca $6 \mu \mathrm{m}$ in Giemsa-stained smears and is larger than the $3 \mu \mathrm{m}$ reported in glutaraldehyde-fixed tissue culture of the grackle form. ${ }^{4,12}$ This may reflect a difference in the processing method used. Microgamete size in the opossumpasserine species is comparable to that of the python-rat species (S. orientalis) described by Zaman and Colley ${ }^{1: 5}$ who also used Giemsa-stained smears.

\section{LITERATURE CITED}

1. ASHFORD, R.W. 1977. The fox, Vulpes vulpes, as a final host for Sarcocystis of sheep. Ann. Trop. Med. Parasit. 71: 29-34.

2. BOX, E.D. and D.W. DUSZYNSKI. 1978. Experimental transmission of Sarcocystis from icterid birds to sparrows and canaries by sporocysts from the opossum. J. Parasit. 64: 682-688.

3. DUSZYNSKI, D.W. and E.D. BOX. 1978. The opossum (Didelphis virginiana) as a host for Sarcocystis debonei from cowbirds (Molothrus ater) and grackles (Cassidix mexicanus, Quiscalus quiscula). J. Parasit. 64: 326-329.

4. FAYER, R. 1972. Gametogony of Sarcocystis sp. in cell culture. Science. 175; 6567.

5. 1974. Development of Sarcocystis fusiformis in the small intestine of the dog. J. Parasit. 60: 660-665.

6. MARKUS, M.B. 1978. Sarcocystis and sarcocystosis in domestic animals and man. Adv. Vet. Sci. Comp. Med. 22: 159-193.

7. MEHLHORN, H. and A.O. HEYDORN. 1978. The Sarcosporidia (Protozoa, Sporozoa): Life Cycle and Fine Structure. In: Advances in Parasitology, W.H.R. Lumsden, R. Muller, and J.R. Baker, Eds., Vol. 16, Academic Press, NY, pp. 43-92.

8. — and E. SCHOLTYSECK. 1974. Light and electron microscope studies on stages of Sarcocystis tenella in the intestine of cats. Z. Parasitenk. 43: 251270.

9. MUNDAY, B.L., I.K. BARKER and M.D. RICKARD. 1975. The developmental cycle of a species of Sarcocystis occurring in dogs and sheep, with observations on pathogenicity in the intermediate host. Z. Parasitenk. 46: 111-123. 
10. RUIZ, A. and J.K. FRENKEL. 1976. Recognition of cyclic transmission of Sarcocystis muris by cats. J. Inf. Dis. 133: 409-418.

11. SCHOLTYSECK, E. and M. HILALI. 1978. Ultrastructural study of the sexual stages of Sarcocystis fusiformis (Railliet, 1897) in domestic cats. Z. Parasitenk. 56: 205-209.

12. VETTERLING, J.M., N.D. PACHECO and R. FAYER. 1973. Fine structure of gametogony and oocyst formation in Sarcocystis sp. in cell culture. J. Protozool. 20: 613-621.

13. ZAMAN, V. and F.C. COLLEY. 1975. Light and electron microscopic observations of the life cycle of Sarcocystis orientalis $\mathrm{sp}$. $\mathrm{n}$. in the rat (Rattus norvegicus) and the Malaysian reticulated phython (Python reticulatus). $\mathrm{Z}$. Parasitenk. 47: 169-185.

Received for publication 2 October 1979 